\title{
Analysis of climate change and future projection of rainfall, temperature, and potential evapotranspiration in Riam Kanan catchment area, Banjar Regency, South Kalimantan
}

\author{
Olivia Putri Purnama ${ }^{1, *}$, Hadi Kardhana $^{2}$, Harry Indrawan $^{3}$, Rasgianti $^{3}$, M. Cahyono ${ }^{2}$, dan Anna Nurganah Chaidar ${ }^{2}$ \\ ${ }^{1}$ Magister Study Program of Water Resources Management, Faculty of Civil and Environmental Engineering, Institut Teknologi \\ Bandung, Bandung, Indonesia \\ ${ }^{2}$ Water Resources Engineering Resources Group, Faculty of Civil and Environmental Engineering, Institut Teknologi Bandung, \\ Bandung, Indonesia \\ ${ }^{3}$ Research and Development Center of Electricity, PT. PLN (Persero), Jakarta, Indonesia
}

\begin{abstract}
Climatic conditions in Indonesia warm up indicated by the increasing of the average annual temperature by $0.3^{\circ} \mathrm{C}$. This may cause higher water evaporation and increased rainfall intensity. Changes in rainfall patterns shift the start of the rainy season to be slower and end faster. These changes the dry season to become longer with shorter time intervals. In case of dam operation, dam manager needs to adapt the effects of climate change. This paper presents trend and future projection in Riam Kanan Catchment Area, Banjar Regency, South Kalimantan. Climate change historical trend analysis was carried out with the observation data used were rainfall and maximum temperature from BMKG climatology station, Banjarbaru Station, in the period 1983 2017. Future projection analysis was carried out by using RCP 2.6 and RCP 8.5 scenario data for projecting rainfall and temperature in the period $2018-2100$. The result shows that the rainfall, maximum temperature, and evapotranspiration trends in Banjarbaru from 1983 - 2017 were not too significant by $+0.1 \mathrm{~mm},-0.5^{\circ} \mathrm{C}$, and $+0.1 \mathrm{~mm}$. While the projection of RCP2.6 and RCP8.5 scenario shows increase by $+0.1 \mathrm{~mm},+0.1^{\circ} \mathrm{C},+0.1 \mathrm{~mm}$ and by $+0.1 \mathrm{~mm},+3.3^{\circ} \mathrm{C}$, and $+0.1 \mathrm{~mm}$. Keywords: Climate Change, Trend, Rainfall, Temperature, Evapotranspiration, RCP 2.6, RCP8.5.
\end{abstract}

\section{Preliminary}

Climate is an average weather condition over a long period of time. The climate on earth is strongly influenced by rainfall and air temperature. There are several climate classifications on this earth that are determined by geographical location. In Indonesia, we can generally call it a tropical climate, middle latitudes, and high latitudes. The entire Indonesian archipelago is located along the equator between $6^{\circ} \mathrm{N}-11^{\circ} \mathrm{S}$ and $95^{\circ}-141^{\circ} \mathrm{E}$ including tropical regions whose main characteristics are always high temperatures. Climate conditions in the world are always changing, both according to space and time. Climate change is based on space, namely climate change locally and globally.

Climate change is based on time, namely the climate can change in the form of cycles, both daily, seasonal, annual, and decades. Climate change is a change that has a real upward or downward tendency. Climate change in the world cannot be avoided due to global warming, both directly and indirectly and will affect various aspects of life. Global climate change is caused, among others, by the increase in gas concentrations in the atmosphere. This has happened since the industrial revolution, where energy sources derived from coal, petroleum, and gas, as well as those that dispose of atmospheric gas waste, such as carbon dioxide $\left(\mathrm{CO}_{2}\right)$, methane $\left(\mathrm{CH}_{4}\right)$, and nitrous oxide $\left(\mathrm{N}_{2} \mathrm{O}\right)$ increase [1]. The sun that shines on the earth also produces heat radiation captured by the atmosphere so that the temperature is comfortable for human life. If the earth's atmosphere is then filled with gas, a blanket effect occurs like what happens in a greenhouse, which is the radiation of geothermal energy released into the air held by a gas blanket so that the temperature rises and becomes hot. The more gas released into the air, the thicker the blanket of the earth, the warmer the earth's temperature. Based on the report of the IPCC (Intergovernmental Panel on Climate Change) research group, indicate the rate and duration of warming in the 20th century was greater than in previous centuries [2]. The air condition in Indonesia becomes hotter with the average annual air temperature has increased by approximately $0.3^{\circ} \mathrm{C}$ and caused high evaporation of water, so the atmosphere gets wet and the intensity of rainfall increases [3]. Changes in rainfall patterns cause the beginning of the rainy season to be slower and end faster, so the dry season becomes longer with shorter time

\footnotetext{
Corresponding author: purnamaoliviaputri@gmail.com
} 
intervals [4]. Some of the impacts of global climate change, including:

- An increase in extreme climate events, namely an increase in rain in the rainy season causes a high frequency of flood events, while a decrease in rainfall in the dry season will increase the risk of drought.

- All regions of Indonesia experience an increase in air temperature, at a rate that is lower than the subtropical region, so that the risk of forest fires and melting of the polar ice caps increases so that the sea level rises so that it can drown the island and prevent the flow of river water into the sea and ultimately cause flooding lowland.

- In the southern region of Indonesia, rainfall has decreased, while the northern region will experience increased rainfall. Changes in the rain pattern cause changes in the beginning and the length of the rainy season [5].

- The trend of changes in rainfall patterns is certainly very much related to the agricultural sector. In the southern part of Indonesia, the shorter rainy season will make it difficult to increase the cropping index (IP) so that varieties are shorter and without rehabilitation of irrigation networks. Conversely, in the northern part of Indonesia, increasing rainfall in the rainy season will increase the chances of IP, but the condition of the land is not as good as in Java.

- Result in El Nino and La Nina. El Nino is the event of warming sea surface temperatures on the west coast of Peru to Ecuador which has caused global climate disturbances. La Nina is a normal weather condition after El Nino.

The fact that global temperatures are continuously increasing tends to result in an increase or decrease in rainfall variables and evaporation as the two main components in the hydrological cycle. Changes in infiltration, precipitation and evaporation cause the water balance in the hydrological cycle to change which can affect the reservoir operating pattern. The magnitude of the projected value causes various experts to focus on how to adapt, mitigate and avoid the impact of global and regional damage [6,7]. The participation of each region must be included in climate change monitoring, in this case the parameters examined are rainfall, and temperature (maximum temperature). Therefore, the dam manager needs to participate in anticipating the effects of climate change on the reservoir operating pattern. To analyse climate change trends and projected temperature and rainfall, research areas were used in the Riam Kanan Catchment Area in Banjar Regency, South Kalimantan.

\section{Description of Riam Kanan catchment area}

The catchment area is indicated by major dam lies at its outlet with area of $1.048 \mathrm{~km}^{2}$. The dam named Riam Kanan Dam which is located in Aranio Village, Martapura District, Banjar Regency, South Kalimantan $\left(3^{\circ} 31^{\prime} 02.3^{\prime \prime S}\right.$ and $\left.115^{\circ} 00^{\prime} 30.2^{\prime \prime} \mathrm{E}\right)$. The idea of developing the dam was promoted by Ir. Pangeran Muhammad Noor, former minister of Public Works for the period of 1956 -
1959, who come from South Kalimantan. The first preliminary study was explored during the year 1958 1959, and concluded that Riam Kanan river basin has appropriate topographic situation and high potential of water resources for generating hydro power because of large and good watershed condition. The development of Riam Kanan Dam was realized through the assistance of the government of Japan. Design of the dam was prepared by Nippon Koei Co. Ltd., while the construction was carried out by Nippon Kokkan (for mechanical and materials), Fuji Electric and Toyomenta (specialized in electrical and machine), and Indonesia contractor PT Wijaya Karya. The construction period was initialized by developing 25 kilometers of access road from the city of Banjarbaru in 1963 - 1964, while the construction of the dam was accomplished at 1973 and inaugurated by the president on June 30, 1973 for starting the operation. Riam Kanan Dam, a 57 meter high of homogeneous earth fill type dam, has a storage capacity of 600 million $\mathrm{m}^{3}$ with surface area of 9.200 hectares, has a main function to generating electric hydropower with the install capacity of 3x10 Megawatts. The dam, on January 19, 1980 was named as Ir. Muhammad Noor Hydro Power Dam, to dedicate him as the promoter of developing the first dam in Kalimantan.

\section{Data and method}

\section{a. Data}

The data used in generating historical trends are observational data on rainfall and maximum temperature from the BMKG climatology station with the name Banjarbaru Station. The station is located about $15 \mathrm{~km}$ west of the Riam Kanan Dam. At this station rainfall data is quite complete for 35 years (1983 - 2017) which can represent climate variations. While the data used as predictors of the trend conditions of projected rainfall, average temperature, and evapotranspiration in Riam Kanan originated from the RCP2.6 and RCP8.5 scenario data for the period 2018 - 2100. All data published by BMKG had through internal validation process by the institution.

\section{b. Method}

Trend analysis is divided into 35 years and 10 years for rainfall and maximum temperature using the Linear trend method. Maximum temperature was used to cover daylight temperature variations that more useful in term of adaptation and mitigation. The software used is Microsoft Excel and ArcGIS.

Evapotranspiration is the process of losing water to the atmosphere from soil and plants. Evapotranspiration occurs during the day when the presence of the sun causes water from the soil and plants to evaporate. Potential evapotranspiration is a value that describes the needs of the environment, a set of vegetation, or an agricultural area to evapotranspiration which is determined by several factors, such as the intensity of the sun's radiation, wind speed, leaf area, temperature, and air pressure. To get the historical trend of evapotranspiration from BMKG data in Banjarbaru Station for the period 1983 - 2017 using the 
Penman-Monteith method because there are quite a lot of data such as temperature, solar radiation, wind speed, humidity and air pressure so the results are more accurate. To obtain ETP the Penman-Monteith method [8] can be done in the following ways:

- Gathering climatological data: Maximum temperature (T), Sun radiation (n/N), Average Air Pressure (P), Air Humidity (RH), Average Wind Speed (U)

- Collect topographic data: Elevation and Latitude $(\varphi)$ of the climatology station

- Calculates latent heat for evaporation based on average temperature data $(\lambda)$

$$
\lambda=2,501-\left(2,361 \times 10^{-3}\right) T
$$

$\lambda$ : latent heat for evaporation $(\mathrm{MJ} / \mathrm{kg})$

$\mathrm{T}$ : average temperature $\left({ }^{\circ} \mathrm{C}\right)$

- Calculate atmospheric pressure $(P)$

$$
P=P_{o}\left(\frac{T_{k o}-\tau\left(z-z_{o}\right)}{T_{k o}}\right)^{\frac{g}{\tau R}}
$$

$\mathrm{P}:$ atmospheric pressure at elevation $\mathrm{z}(\mathrm{kPa})$

Po : atmospheric pressure at sea level $(\mathrm{kPa})$

$\mathrm{z}$ : elevation $(\mathrm{m})$

zo : reference elevation $(\mathrm{m})$

g : gravity $=9,8 \mathrm{~m} / \mathrm{s}^{2}$

$\mathrm{R}$ : specific gas constant $=287 \mathrm{~J} / \mathrm{kg} / \mathrm{K}$

Tko : temperature at elevation zo $(\mathrm{K})$

$\tau \quad:$ saturated air lapse rate constant $=0,0065 \mathrm{~K} / \mathrm{m}$

If the air pressure on a station isn't available, then use the assumption $\mathrm{Tko}=293 \mathrm{~K}$ untuk $\mathrm{T}=20^{\circ} \mathrm{C}$ dan $\mathrm{Po}=$ $101,3 \mathrm{kPa}$ pada $\mathrm{zo}=0$.

- Calculate psychrometric constants $(\gamma)$

$$
\gamma=0.00163 \cdot \frac{P}{\lambda}
$$

$\gamma:$ psychrometric constants $\left(\mathrm{kPa} /{ }^{\circ} \mathrm{C}\right)$

- Calculate saturated vapor pressure based on average temperature data $\left(e_{s}\right)$

$$
e_{s}=0.611 \exp \left(\frac{17,27 T}{T+237,3}\right)
$$

- Calculate actual vapor pressure based on average humidity data $\left(e_{a}\right)$

$$
e_{a}=e_{s} x R H
$$

$\mathrm{RH}$ : average relative humidity (\%)

- Calculate the slope of the vapor pressure curve to the average temperature $(\Delta)$

$$
\Delta=\frac{4098 x e_{s}}{(T+237.3)^{2}}
$$

$\Delta:$ the slope of the vapor pressure curve to the average temperature $\left(\mathrm{kPa} /{ }^{\circ} \mathrm{C}\right)$

$e_{s}:$ saturated vapor pressure $(\mathrm{kPa})$

- Calculate wind speed at a height of 2 meters $\left(U_{2}\right)$

$$
U_{2}=U_{z}\left(\frac{4,87}{\ln (67,8 z-5.42)}\right)
$$

$U_{2}$ : wind speed at an altitude of $2 \mathrm{~m}(\mathrm{~m} / \mathrm{s})$

$U_{z}$ : wind speed at an altitude of $\mathrm{z} \mathrm{m}(\mathrm{m} / \mathrm{s})$

$\mathrm{z}$ : height of the wind speed meter $(\mathrm{m})$

- Calculate emissivity $\left(\varepsilon^{\prime}\right)$

$$
\varepsilon^{\prime}=0,34-0,14 \sqrt{e_{a}}
$$

$\varepsilon^{\prime}:$ atmospheric emissivity

$e_{a}:$ actual vapor pressure $(\mathrm{kPa})$

- Calculate the serial number of the day of the year for normal years ( $J_{\text {bulanan }}$, Gommes 1983)
$J_{\text {bulanan }}=$ Integer $(30,42 M-15,23)$

$\mathrm{J}:$ serial number of days in the year (Julian days)

$\mathrm{M}:$ months (1-12)

$\mathrm{D}$ : days in month $(1-31)$

If the year is normal and $\mathrm{M}<3$, the value of $\mathrm{J}+2$.

If leap year and $\mathrm{M}>2$, the value of $\mathrm{J}+1$. Leap year is the year which is divided by 4 .

- Calculate the angle of declination of the sun $(\delta)$

$$
\delta=0,409 \sin (0,0172 J-1,39)
$$

- Calculate the angle at sunset $\left(\omega_{s}\right)$

$$
\omega_{s}=\arccos (-\tan \varphi \tan \delta)
$$

$\delta:$ angle of declination of the sun $(\mathrm{rad})$

$\varphi$ : latitude (rad)

If it's at the northern latitude the value is positive, at the southern latitude the value is negative.

- Calculate the relative distance between earth and sun $\left(d_{r}\right)$

$$
d_{r}=1+0,033 \cos (0,0172 J)
$$

- Calculate extra-terrestrial solar radiation $\left(R_{a}\right)$

$R_{a}=37,6 d_{r}\left(\omega_{s} \sin \varphi \sin \delta+\cos \varphi \cos \delta \sin \omega_{s}\right)$

$d_{r}$ : relative distance between earth and sun

$\omega_{s}$ : angle at sunset (rad)

- Calculate solar radiation $\left(R_{S}\right)$

$$
R_{s}=\left(0,25+0,5 \frac{n}{N}\right) R_{a}
$$

$\mathrm{n}$ : long sun shines in one day (hour)

$\mathrm{N}$ : long maximum sun shines in one day (hour)

$\mathrm{Ra}$ : extra-terrestrial solar radiation $\left(\mathrm{MJ} / \mathrm{m}^{2} /\right.$ day)

- Calculate short-wave radiation $\left(R_{n s}\right)$

$$
R_{n s}=(1-\alpha) R_{s}
$$

$\alpha$ : canopy reflection coefficient $=0,23$ (this coefficient value is influenced by the condition of the cover crop, in some literature using a range of values of $0.23-0.25$ ) Rs : solar radiation $\left(\mathrm{MJ} / \mathrm{m}^{2} /\right.$ day)

- Calculate the cloud closing factor $(f)$

$$
f=0,9 \frac{n}{N}+0,1
$$

- Calculate long wave radiation $\left(R_{n l}\right)$

$$
R_{n l}=f\left(\varepsilon_{a}-\varepsilon_{v s}\right) \sigma T_{k}{ }^{4}
$$

$\mathrm{Rnl}$ : long wave radiation ( $\mathrm{MJ} / \mathrm{m}^{2} /$ day)

f : cloud cover factor (non-dimensional)

$\varepsilon_{a}$ : effective atmospheric emissivity

$\varepsilon_{v s}:$ value of emissivity by vegetation and soil $\approx 0,98$

[9]

$\sigma$ : Stefan-Boltzman constant value $=4,90 \times 10^{-9}$ $\mathrm{MJ} / \mathrm{m}^{2} / \mathrm{K} 4 /$ day

$\mathrm{Tk}$ : average temperature $(\mathrm{K})$

- Calculate net solar radiation above the plant surface $\left(R_{n}\right)$

$$
R_{n}=R_{n s}-R_{n l}
$$

Rns : short wave radiation $\left(\mathrm{MJ} / \mathrm{m}^{2} /\right.$ day)

- Calculate reference plant evapotranspiration

$$
\text { ETo }=\frac{0.408 \Delta R n+\gamma \frac{900}{(T+273)} U_{2}\left(e_{s}-e_{a}\right)}{\Delta+\gamma\left(1+0.34 U_{2}\right)}
$$

ETo : reference plant evapotranspiration ( $\mathrm{mm} /$ day)

$\mathrm{Rn}$ : net solar radiation above the plant surface $\left(\mathrm{MJ} / \mathrm{m}^{2} /\right.$ day)

In this study, we can also use CMIP5 data (Climate Model Inte Comparison Project 5) as a predictor of future projection trend conditions from several important 
variables in water balance analysis such as rainfall, average temperature, and evapotranspiration obtained from website platform [10]. This is one method to predict climate stochastically based on existing observation data, namely those proposed by the IPCC. In 2013, the IPCC proposed 4 CMIP5 scenarios, namely RCP 8.5, RCP 6.0, RCP 4.5, RCP 2.6. RCP (Representative Concentration Pathway) which is based on the effect of global warming on the parameters of radiation intensity due to human

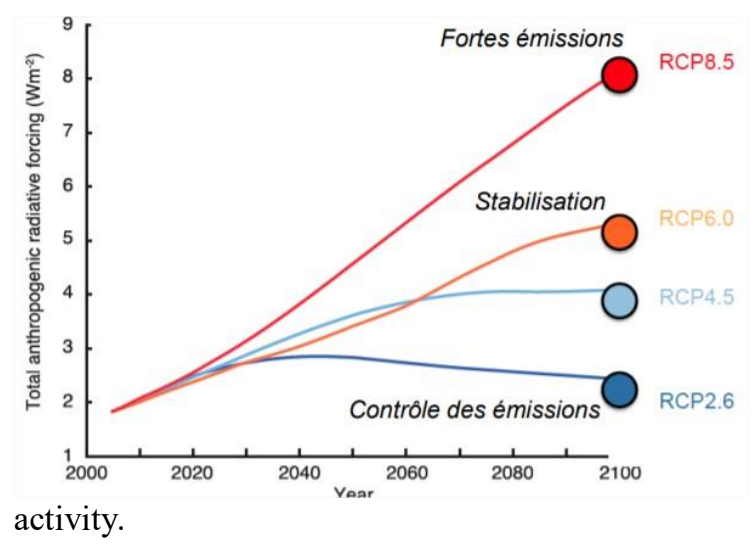

Fig. 1. Representative concentration pathway

The first scenario ( $\mathrm{RCP} 8.5$ ) is a pessimistic scenario where the rate of increase in radiation intensity is the same as the current level and there is no collective effort by countries in the world to reduce that level. While the last scenario (RCP 2.6) is an optimistic scenario with collective efforts that are ideal for maintaining and even reducing radiation intensity. Members of the World Meteorological Agency such as KNMI [10] publish these scenario-based forecasts in a comprehensive database with open access.

\section{Results and discussion}

Some graphs of rainfall and maximum temperature trends with a period of 35 years, depicture on Figure 2. There are climate variations that are generally found due to the influence of El Nino and La Nina, so that dry and wet periods have a noticeable cycle. Some exceptions due to a more detailed weather system resulted in extreme drought occurring in 1991, 1997, 2002 and 2015. This period is usually indicated in reservoirs with drastically decreased water level, normal water levels not met, or minimal generated energy. While excess water occurred in 1988, 1989, 1995, 1998, 2010 and 2013. This period was indicated in reservoirs with more than normal water level so that a large possibility of spill occurred. Based on data processing with linear trends, a trend per 35 years in Banjarbaru for rainfall parameters has a downward trend but not significant, and for maximum temperature (usually afternoon temperatures) parameters has a decreasing trend of $\pm 0.5^{\circ} \mathrm{C}$.

Climate data includes humidity, sunlight, temperature, air pressure, and wind. There is no data on the evaporation pan in the reservoir, the Pan Evaporation data that is owned is data from the 1960s [11] at the Awang Bangkal location. There is a historic trend that is quite drastic, namely a decrease in air humidity and wind speed. Such conditions usually have collective indications will growing sense of discomfort. Air pressure for Banjarbaru Station with an elevation of 55 meter is 100.7 milibars.

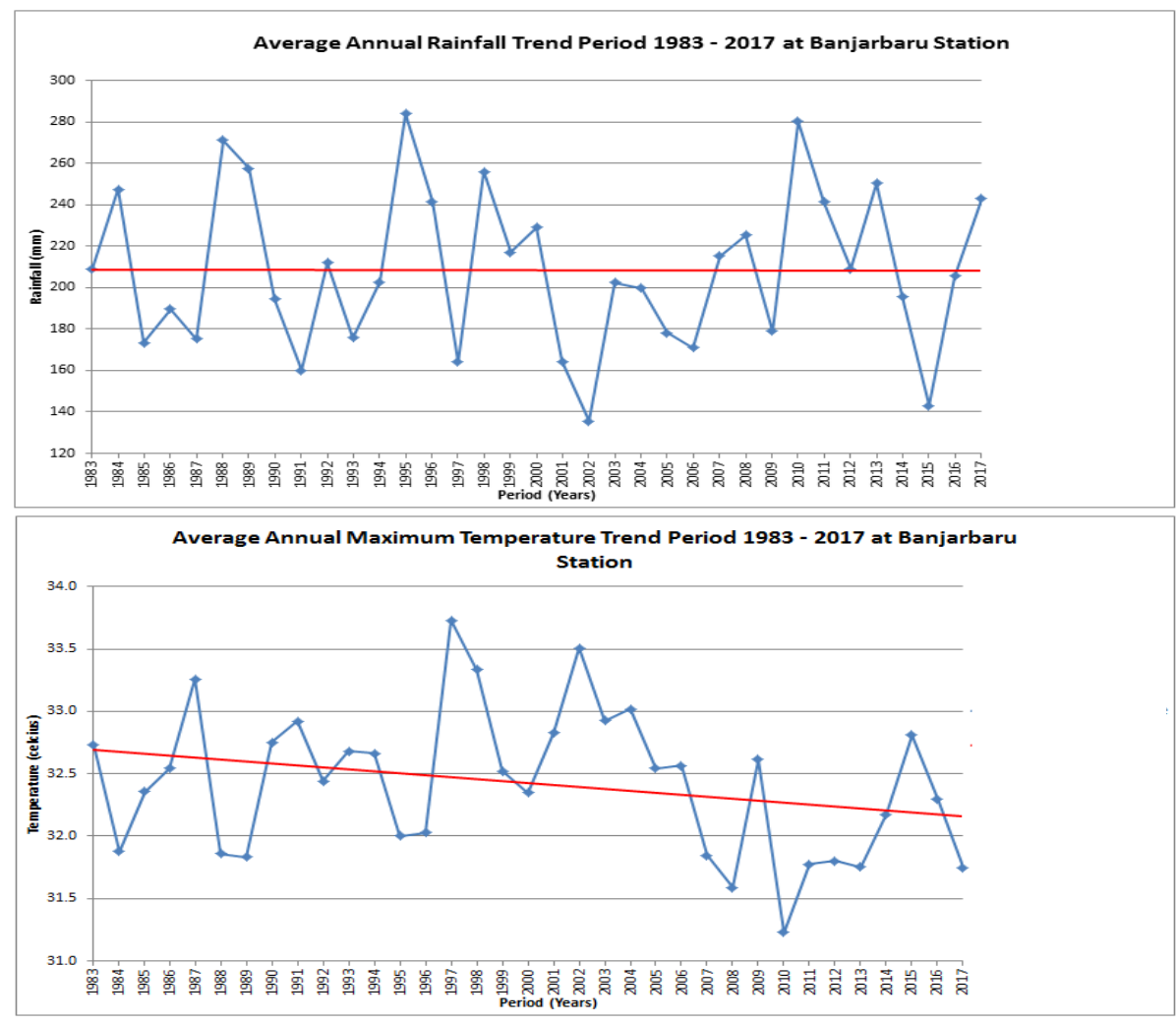

Fig. 2. The average annual rainfall and maximum temperature trend 

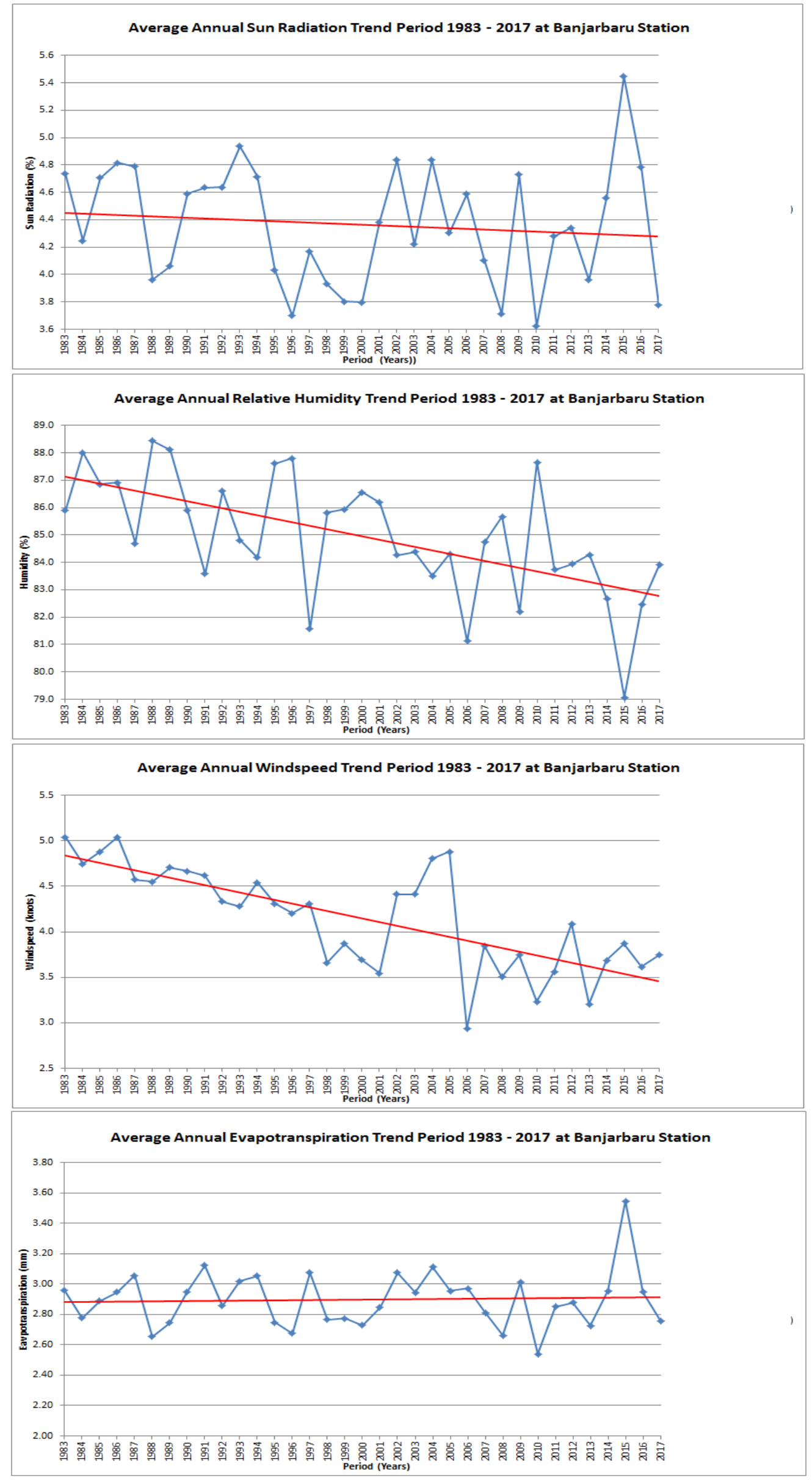

Fig. 3. The average annual sun radiation, relative humidity, wind speed, and evapotranspiration trend 
Although the maximum temperature trend used in the calculation of evapotranspiration shows an decreasing trend and other climatic parameters such as sunlight, air pressure, humidity, and wind speed on average show a downward trend also, but the results of the calculation of evapotranspiration by the Penman-Monteith method shows a trend per 35 years tends to increase by $\pm 0.01 \mathrm{~mm}$, with calibration from the pan evaporation data at the Awang Bangkal location. The following is a comparison of the average pattern per 10 years for the parameters of rainfall, maximum temperature, and evapotranspiration compared to the normal pattern:
Time series analysis shows that changes in temporal distribution of rain indicate a dry period with a significant decrease in rainfall in September and October. Maximum rain still occurs in December and January so the initial position of the optimization calculation must consider this condition. For temporal variation in maximum temperature is decreasing except in October. The smallest maximum temperature occurs in January and in the period of 2011 - 2017 has the highest maximum temperature fluctuation of $\pm 0.4^{\circ} \mathrm{C}$. Then for the evapotranspiration, almost all periods approach the normal pattern except for the period 2011 - 2017 which has a slightly fluctuation of $\pm 0.1 \mathrm{~mm}$.
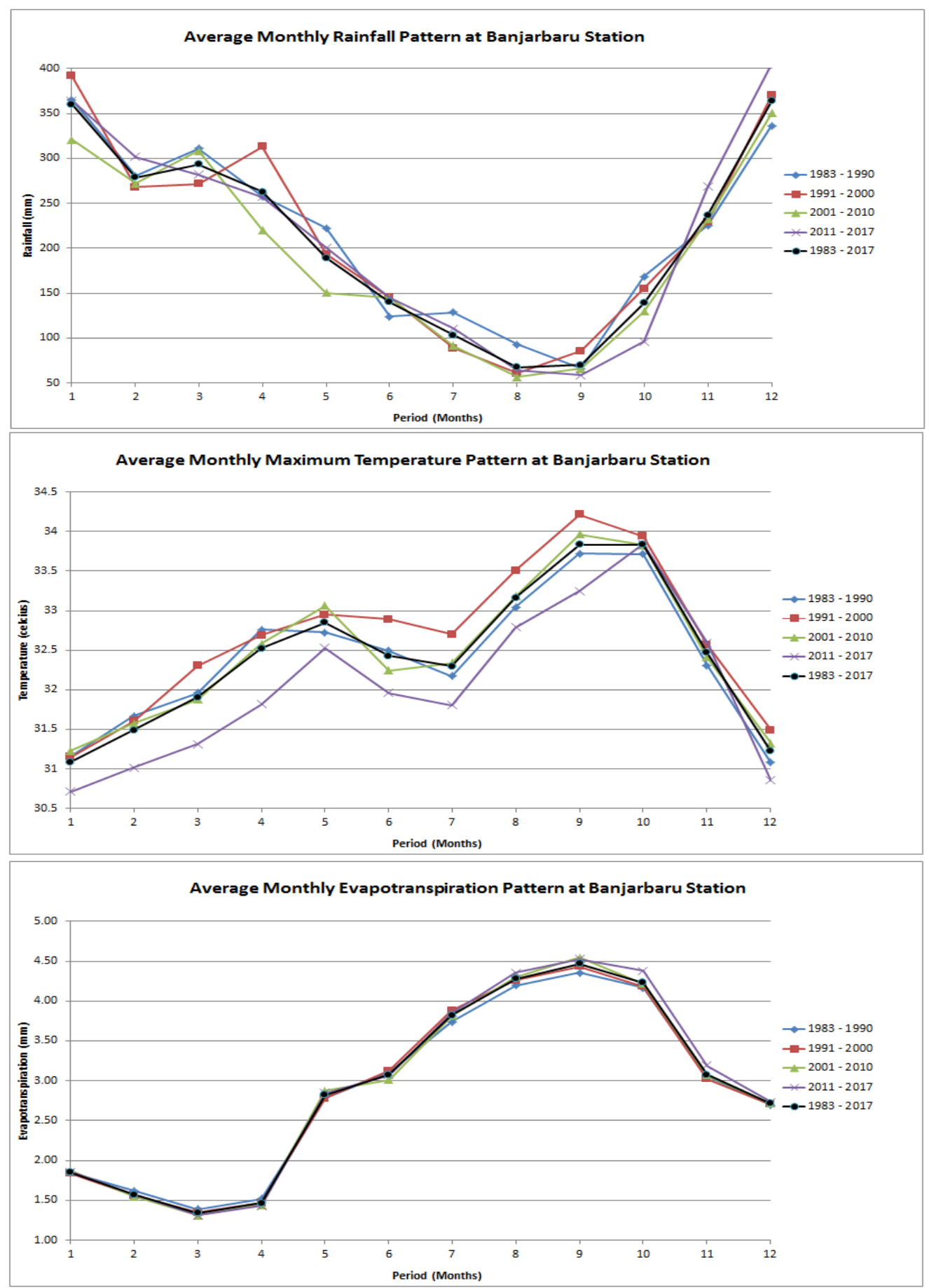

Fig. 4. Comparison of average patterns of rainfall, temperature, and evapotranspiration 
Following are the projection results for the rainfall, average temperature, and evapotranspiration trends in the Banjarbaru region using RCP2.6 and RCP8.5 scenario data in the period $2018-2100$ :
The RCP system uses a large cell grid so that the results at a particular location, in this case is Riam Kanan, are the result of the cell grid interpolation. Therefore, the standar deviation between historical data trend and future projection data trend is not similiar.

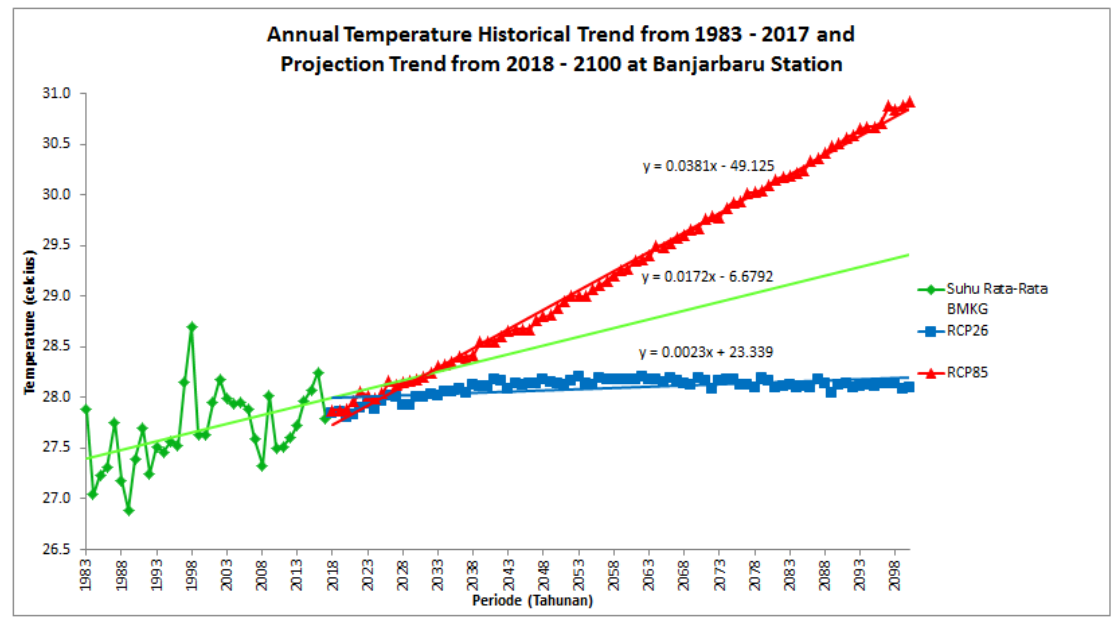

Fig. 5. Temperature projection in Riam Kanan (2018 - 2100)

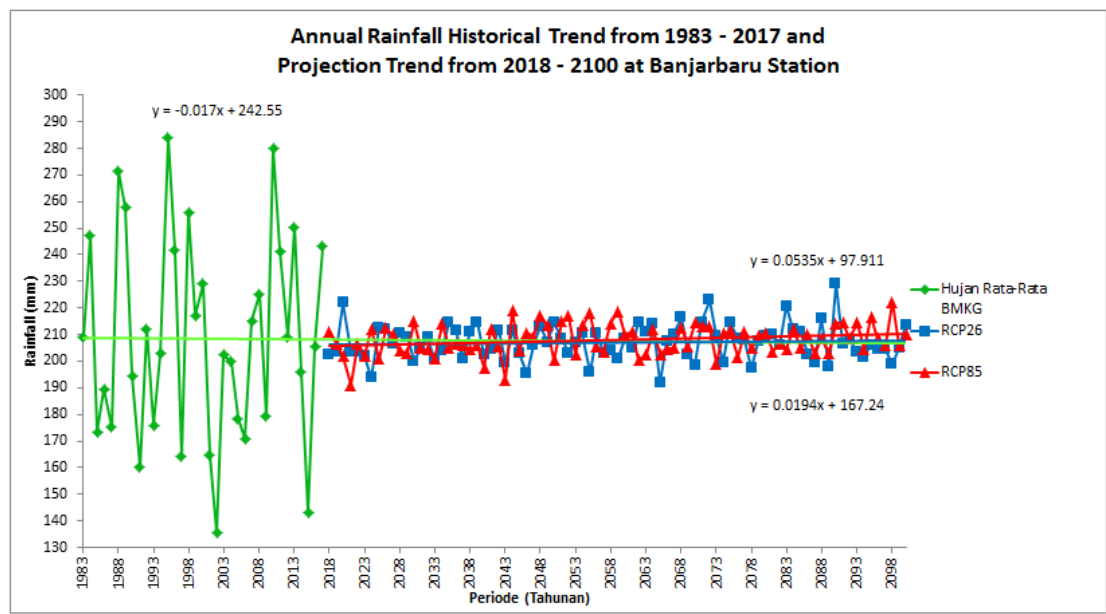

Fig. 6. Rainfall projections in Riam Kanan (2018 - 2100)

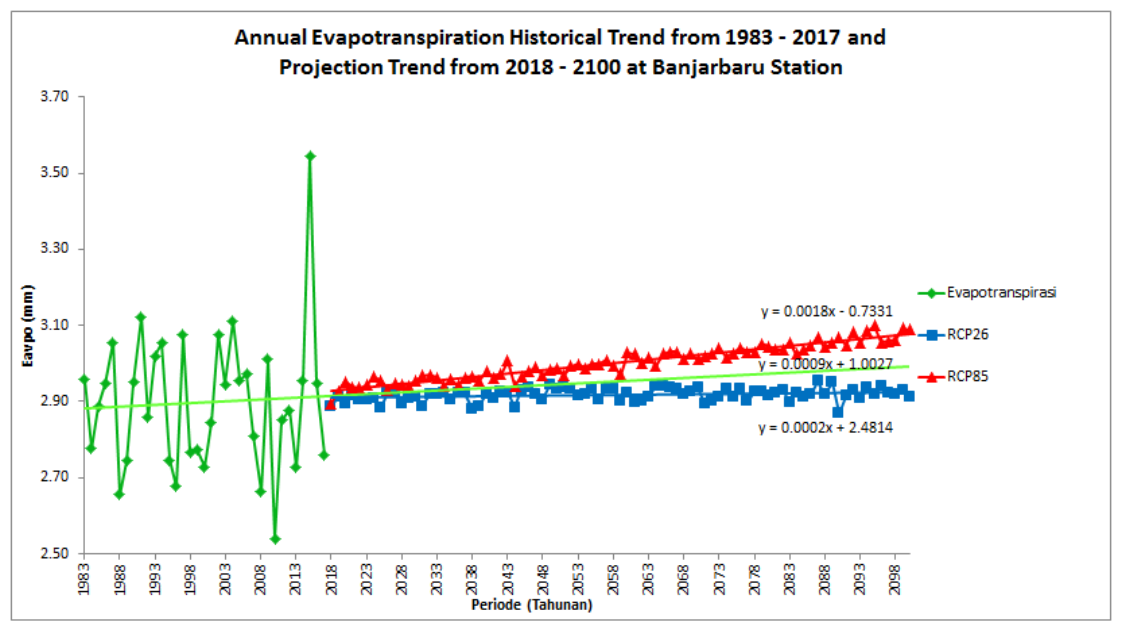

Fig. 7. Evapotranspiration projection in Riam Kanan (2018 - 2100) 
Based on the projection of RCP2.6 and RCP8.5 data for rainfall, the forecast results show that both optimistic and pessimistic scenarios show that there is a trend of increasing rainfall. Nevertheless the rate of increase in 50 years is less than $1 \%$ so that it can be considered insignificant. Then the pessimistic scenario (RCP8.5) shows that an increase in temperature in the next 50 years can reach $1.6^{\circ} \mathrm{C}$, while the optimistic scenario (RCP2.6) has no increase in temperature. When using a historical trend, the increase in temperature is $0.8^{\circ} \mathrm{C}$ in the next 50 years. For evapotranspiration projection, the pessimistic scenario (RCP8.5) shows that the increase in evapotranspiration in the next 50 years is $0.1 \mathrm{~mm}$ from the present value. So, that the increase is less than $5 \%$ of the present value of evapotranspiration. Thus in the context of the water balance, it can be expected that there will be a decrease in the water supply at a not too significant rate.

\section{Conclusion}

Based on various analysis in this study it can be concluded, that the analysis of rainfall, maximum temperature, and evapotranspiration trends from observation data in Riam Kanan for period $1983-2017$ in general shows that the trend changes was not too significant by $+0.1 \mathrm{~mm},-0.5^{\circ} \mathrm{C}$, and $+0.1 \mathrm{~mm}$. While the projection of RCP2. 6 and RCP8.5 scenario data for period $2018-2100$ shows an increasing trend by $+0.1 \mathrm{~mm}$, $+0.1^{\circ} \mathrm{C},+0.1 \mathrm{~mm}$ and by $+0.1 \mathrm{~mm},+3.3^{\circ} \mathrm{C}$, and $+0.1 \mathrm{~mm}$. With this it can be stated that indications of climate change in the Riam Kanan region is not as significant.

\section{References}

1. O. Soemarwoto, Analisis Mengenai Dampak Lingkungan. Gadjah Mada University Press. Yogyakarta. (1999)

2. IPCC. The Science of Climate Change, Contribution of Working Group I to the Third Assessment Report of the Intergovernmental Panel on Climate Change [M]. Cambridge: Cambridge University Press. (2001)

3. U. Firman, Fluktuasi Udara dan Trend Variasi Curah Hujan Rata-Rata Diatas $100 \mathrm{~mm}$ di Beberapa Wilayah Indonesia Vol.5 No.3. Jurnal meteorologi Klimatologi dan Geofisika. (2009)

4. S. Diposaptono, Budiman, dan Firdaus A. Menyiasati Perubahan Iklim di Wilayah Pesisir dan Pulau-Pulau Kecil. Bogor (ID): PT. Sarana Komunikasi Utama. (2009)

5. S. Budiastuti, Fenomena Perubahan Iklim dan Kontinyuitas Produksi Pertanian: Suatu Tinjauan Pemberdayaan Sumber Daya. (2010)

6. D. Murdiyarso, CDM: Mekanisme Pembangunan Bersih. Seri Perubahan Iklim. Penerbit Buku Kompas. Jakarta. (2003a)

7. D. Murdiyarso, Protokol Kyoto, Implikasi Bagi Negara Berkembang. Seri Perubahan Iklim. Penerbit Buku Kompas. Jakarta. (2003b)

8. Badan Standarisasi Nasional. SNI 7745:2012 tentang Tata Cara Perhitungan Evapotranspirasi Tanaman
Acuan dengan Metode Penman-Monteith. Badan Standarisasi Nasional. Jakarta. (2012)

9. M.E. Jensen, R.D. Burman and R.G. Allen Evapotranspiration and Irrigation Water Requirements. ASCE Manual No. 70. (1990)

10. http://climexp.knmi.nl/start.cgi, accessed on August 18,2018

11. Nippon Koei K.K. Preliminary Report on Riam Kanan Project, (1962)

12. http://dataonline.bmkg.go.id/home, accessed August 1,2018

13. https://nptel.ac.in/courses/105102015/gis\%20done/c ase $\% 20$ study/Watershed $\% 20$ Delineation $\% 20$ by $\% 20$ ArcSWAT.html, accessed on August 3, 2018

14. http://www.menlhk.go.id/berita-68-pengendaliankebakaran-hutan-dan-lahan-tahun-2016-oleh-timterpadu-karhutla-kministry-lingkungan-h.html, accessed on 7 August 2018

15. http://tanahair.indonesia.go.id/portalweb/download/aoi, accessed on August 13, 2018

16. http://webarchive.iiasa.ac.at/Research/LUC/External Worldsoildatabase/HTML/LandUseShares.html?sb= 9, accessed on August 15, 2018

17. https://earthexplorer.usgs.gov/logout/expire, accessed on August 17, 2018

18. https://giovanni.sci.gsfc.nasa.gov/, accessed on 21 August 2018

19. http://disc.sci.gsfc.nasa.gov/recipes/?q=recipes/How -to-Import-Gridded-Data-in-NetCDF-Format-intoArcGIS, accessed on August 23, 2018 